\title{
Neuroznanstvena dekonstrukcija ideologiziranog »beznađa« vegetativnoga stanja
}

Anto Čartolovni*

anto.cartolovni@unicath.hr
UDK: 616.8-009.831:179

Pregledni članak / Review Primljeno: 11. prosinca 2017. Prihvaćeno: 21. siječnja 2018.

Recentna neuroznanstvena istraživanja propituju dosadašnju predrasudu o vegetativnom stanju kao »beznadnom"stanju. Rezultati ovih otkrića ne samo da ruše već postojeće predrasude prema osobama u vegetativnom stanju, već daju $i$ nov uvid u epistemološku problematiku točnosti dijagnosticiranja aktualnog stanja, popraćenu etičkim i društvenim implikacijama. Pružajući bolje razumijevanje same naravi svijesti i svjesnosti, upućuju na oblik moralne i socijalne odgovornosti prema tim osobama ne ostavljajući mjesta za »beznade«. Stoga je prvotni cilj ovoga rada prikazati kako se uz razvitak uvida u stanje osoba $s$ poremećajem svijesti, na samom početku paralelno razvijala i predrasuda »beznada" kao nuspojava nedovoljnog $i$ neadekvatnog znanja o naravi svijesti kod osoba u vegetativnom stanju. Ova ustaljena predrasuda imala je direktan utjecaj na donošenje kliničkih odluka o mjerama održavanja na životu: od povlačenja nutricije $i$ hidratacije - do pitanja kardio-pulmonarnog oživljavanja pa onda do odvajanja od respiratora, smatrajući da osoba nema nade za oporavak nakon uspostave dijagnoze vegetativnog stanja. Stoga, ova predrasuda »beznada" ne samo da nije ostavila duboko utaban, moralno upitan put za izvođenje pasivne eutanazije, već je, štoviše, bila iskorištena i ispolitizirana kao jedan od glavnih argumenata i primjera pro-eutanazijskih pokreta u borbi za ozakonjenje same eutanazije.

Ključne riječi: Vegetativno stanje, bioetika, neuroetika, poremećaji svijesti, hidratacija $i$ nutricija, beznade.

\footnotetext{
* Dr. sc. Anto Čartolovni, poslijedoktorand, Hrvatsko katoličko sveučilište, Ilica 242, HR-10000 Zagreb.
} 


\section{Uvod}

Posljednja desetljeća istraživanja mozga doživjela su ekspanzijski rast te ostavila neizbrisiv trag u razumijevanju toga nadasve kompleksnog organa. Nova otkrića i bolje razumijevanje doveli su do pronalaženja efikasnijih terapija te većeg razumijevanja kognitivnih procesa koji se odvijaju unutar mozga. No, nažalost, želja za objašnjenjem i razumijevanjem često je navodila na mišljenje da se kompleksna stvarnost, kao što su čovjekov um ili svijest, može jedino razumjeti na osnovi biološkog promatranja interakcije neurona, što je dovelo do pojave tzv. neurologizma. ${ }^{1}$ Stoga, takav način razmišljanja navodi na brzo zaključivanje da svijest direktno ovisi o svome biološkom supstratu, tj. sve dok on postoji i posjeduje kompaktnost, postoji i ona. Drugim riječima, svijest je ili sve ili ništa, tj. nema nekih prijelaznih stanja. Međutim, s vremenom se uvidjelo da to nije točno te osoba koja je u različitim slučajevima doživjela ozljedu ili povredu mozga može ući u stanje kome, ${ }^{2}$ poslije kome može prijeći u stanja poremećaja svijesti (vegetativno stanje, stanje minimalne svijesti) ${ }^{3}$ ili pak u sindrom zaključanog čovjeka (locked-in syndrome), ${ }^{4}$ ili čak na kraju umrijeti moždanom smrću. ${ }^{5}$ Svijest se većinom dijeli na iskustvo svijesti (sebe-svjesnost) i

\footnotetext{
${ }^{1}$ Neurologizam »je teorija koja reducira kompleksne psihološke fenomene na povezane sinaptičke sastave«, Vittoradolfo TAMBONE, Giampaolo GHILARDI, Riduzione consapevole e cooperante, La Clinica Terapeutica, 163 (2012) 3, e133-143, e138.

2 »Kome su po definiciji samo-ograničavajuće i tipično traju od deset dana pa do dva tjedna. Pacijent ili izađe iz kome ili umire na 'tradicionalan' način zastojem srčanog otkucaja i prestankom disanja ili moždanom smrću « (Joseph J. FINS, Rights come to Mind - Brain injury, ethics, and the struggle for consciousness, Cambridge, Cambridge Univerity Press, 2015, 28).

${ }_{3}$ »Vegetativno stanje je produljeno stanje poremećaja svijesti uz očuvanu budnost bez spoznaje o okolini. Nastaje kao posljedica silne disfunkcije moždanih hemisfera s poštedom diencefalona i moždanog debla uz očuvan autonomni sustav i očuvane motorne reflekse i ritam budnost-spavanje. Bolesnici mogu imati očuvane složene reflekse, koji uključuju pokrete očima, zijevanje, nevoljne pokrete na bolni podražaj, ali ne pokazuju nikakvu spoznaju o sebi odnosno o okolini« [MSD priručnik dijagnostike i terapije, Vegetativno stanje, www.msd-prirucnici. placebo.hr/msd-prirucnik/neurologija/stupor-i-koma/vegetativno -stanje (04.11.2017)]. Stanje minimalne svijest (MCS): »Pacijenti u stanju minimalne svijesti (MCS) pokazuju nekonzistentne znake svjesnosti, također su većinom u mogućnosti fokusirati se i slijediti jednostavne naredbe« [Inga STEPPACHER, Michael KAPS, Johanna KISSLER, Will time heal? A long-term follow-up of severe disorders of consciousness, Annals of Clinical and Translational Neurology, 1 (2014) 6, 401-408, 401].

${ }^{4}$ »Sindrom čovjeka zaključanog u vlastito tijelo (locked-in syndrome) je stanje budnosti i očuvane svijesti uz nemogućnost mimike, pomicanja tijela, govora ili komunikacije, osim kodiranim pokretima očiju. Bolesnici imaju očuvane kognitivne funkcije i budni su te otvaraju oči, a imaju očuvane cikluse budnost-spavanje. Oni ne mogu pomicati donji dio lica, žvakati, gutati, govoriti, disati odnosno pomicati udove. Mogući su vertikalni pokreti očima; bolesnici mogu otvarati i zatvarati oči te trepnuti određeni broj puta kako bi odgovorili na pitanje« [MSD priručnik dijagnostike i terapije, Sindrom zaključanog čovjeka, www.msd-prirucnici.placebo. $\mathrm{hr} / \mathrm{msd}$-prirucnik/neurologija/stupor-i-koma/sindrom-zakljucanog-covjeka (14.01.2018)].

5 »Kod moždane smrti, donji dio mozga (moždano deblo, koje povezuje mozak s kičmenom moždinom) i gornji dio mozga (cerebralni kortex) oba odumiru. Moždana smrt, za razliku od konvencionalne - prirodne - definicije smrti, tj. prestanka kardiopulmonarne funkcije,
} 
sadržaj svijesti kao što su mišljenja, vjerovanja, osjećaji, percepcije, intencije, sjećanja i emocije. ${ }^{6}$

Svijest je posljednjih godina postala fokus značajnih rasprava, ${ }^{7}$ osobito jer ima značajnu ulogu u našem procesu donošenja odluka te je zbog toga, za neke bila čak jedan od najvažnijih kriterija smatra li se pacijenta osobom ili ne. No, takva stajališta ne samo da su se zadržala u domeni filozofskih rasprava, već su pronašla svoje uporište i u kliničkom ambijentu, gdje su liječnici gubitak svijesti kod različitih trauma i ozljeda počeli smatrati direktnim vođenjem $\mathrm{k}$ smrti, tj. kasnijim se generaliziranjem gubitak svijesti počinje smatrati negativnim indikatorom i drugih stanja poremećaja svijesti. Takav je negativan stav uzrokovao preuranjene odluke već na početku same dijagnoze, za povlačenje hidratacije i nutricije, tj. surogatnim odlukama o »ne-oživljavanju« ili odvajanju od mehaničkog respiratora.

\section{Začetci »beznađa« vegetativnog stanja kroz povijest}

Druga polovica XX. stoljeća u povijesti je obilježena znatnim tehnološkim napretkom pa tako i u medicini. Pojava je mehaničkog respiratora medicinske stručnjake dovela u nezavidan položaj, uz to još dodatno motivirane izazovima transplantacijske medicine: trebalo je redefinirajti smrt. Stoga, 1968. godine povjerenstvo Sveučilišta Harvard donosi neurološke kriterije za proglašenje osobe mrtvom, poznate kao dokazi za »moždanu smrt «. ${ }^{8}$ U to vrijeme Fred Plum i Jerome B. Posner otkrivaju da neke osobe izlaskom iz kome počnu pokazivati znakove potpune svijesti no zbog svoje paraliziranosti ne mogu odgovoriti na

čovjekova je tvorevina koja je bila potrebna zbog medicinskog razvoja: ventilatora i transplantacije organa. Prije pojave ventilatora ovi pacijenti nisu mogli preživjeti jer moždano deblo nije moglo upravljati autonomnim funkcijama srčanog rada i disanja« (Fins, Rights come to Mind..., 28).

${ }^{6}$ Usp. David A. OAKLEY, Peter W. HALLIGAN, Chasing the rainbow. The non-conscious nature of being, Frontiers in psychology, 8 (2017) 1924.

7 Usp. Neil LEVY, Julian SAVULESCU, Moral significance of phenomenal consciousness, u: Steven LAUREYS, Nicholas D. SCHIFF, Adrian M. OWEN (ur.), Progress in Brain Research, London, Elsevier, 2009, 361-370.

8 »Moždana smrt podrazumijeva besvjesno stanje, nemogućnost samostalnog disanja i trajan gubitak refleksa moždanog debla; spinalni refleksi, uključujući duboke tetivne reflekse, plantarnu fleksiju i reflekse povlačenja na bolni podražaj mogu biti očuvani« [MSD priručnik dijagnostike i terapije, Moždana smrt, www.msd-prirucnici.placebo.hr/msd-prirucnik/neurologija/stupor-i-koma/mozdana-smrt (08.11.2017)]. Više o tome u: Tonči MATULIĆ, Biomedicinska i bioetička rasprava o ljudskoj smrti (I. dio). Od smrti kao nepoznanice do smrti kao totalne smrti mozga, Obnovljeni život, 55 (2000) 2, 169-188; Tonči MATULIĆ, Biomedicinska i bioetička rasprava o ljudskoj smrti (II. dio). Sintetičko-kritička evaluacija uzroka nastanka i nekih relevantnih aspekata konceptualnog pluralizma imanentnog neologizmu »moždana smrt«, Obnovljeni život, 55 (2000) 3, 319-341. 
različite podražaje, te to stanje nazivaju sindromom zaključanog čovjeka. ${ }^{9} \mathrm{U}$ današnje je vrijeme tehnološkim napretkom uspostavljena komunikacija s takvim osobama putem kompjuterske interpretacije treptaja oka ili međusklopa računalo-mozak, tzv. BCI (Brain-computer interface).

Nekoliko godina poslije uočava se razlika između pacijenata kojima je ustanovljena moždana smrt i pacijenata koji su bez svijesti, no imaju neke znakove života neovisno o aparatima, poput disanja, otvaranja očiju ili pak naizmjeničnog ciklusa spavanje-budnost. ${ }^{10}$ Ova je razlika zaintrigirala neurokirurga Bryana J. Jennetta, poznatijeg kao tvorca »Glasgowske ljestvice kome «, ${ }^{11}$ i neurologa Freda Pluma te oni novo stanje nazivaju "perzistentno vegetativno stanje« (PVS) okarakterizirano kao »budnost bez svjesnosti «, ${ }^{12}$ tj. stanje u kojem je osoba, iako otvorenih očiju, nesvjesna sebe i svega što je okružuje. $\mathrm{Na}$ samom početku opisuju ga kao »sindrom bez imena« te, štoviše, nastojeći pronaći prikladno ime koje bi bilo jasnije široj publici, izabiru pojam »vegetativan « referirajući se na očuvane autonomne neurološke funkcije (npr. ciklični ritam buđenja-spavanja, disanja, probave i termoregulacije). ${ }^{13}$

Ovaj jednostavan pojam koji je, po njima, najbolje opisao navedeni »sindrom bez imena«, s vremenom je poprimio i pejorativne konotacije te se za osobe koje se nađu u takvom stanju proširila predrasuda da su »biljke« pa čak i da nisu u potpunosti ljudska bića. No, nisu se ustalile samo predrasude u obliku pejorativnih naziva, već i mišljenja da za te osobe ne postoji mogućnost ili nada za bilo kakav oporavak. Ova nemogućnost oporavka vuče svoje korijene, kako L. Syd M. Johnson navodi, iz tvrdnje Jennetta i Pluma da su osobe u PVS stanju beznadni slučajevi »u nemogućnosti komunicirati i bez nade za oporavkom kao društvena ljudska bića«. ${ }^{14}$ Jennett i Plum na tragu dijagnoze i prognoze »beznađa« $u$ to vrijeme predlažu da, »ako je moguće ubrzo nakon utvrđene ozljede, $u$ trenutku preživljavanja predvidjeti da će posljedica te ozljede biti vegetativno,

\footnotetext{
${ }^{9}$ Fred PLUM, Jerome B. POSNER, The diagnosis of stupor and coma, Philadelphia, FA Davis, 1966, 197.

${ }^{10}$ Usp. Yuri G. PAVLOV i dr., Night sleep in patients with vegetative state, Jurnal of sleep research, 26 (2017) 5, 629-640.

${ }^{11}$ Glasgowska ljestvica kome je neurološki bodovni instrument po kojem se mjeri razina svijesti kod različitih ozljeda mozga.

${ }^{12}$ Usp. Bryan JENNETT, Fred PLUM, Persistent vegetative state after brain damage. A syndrome in search of name, Lancet, 1 (1972) 734-737.

${ }^{13}$ »Pojam vegetativan nervni sustav datira iz 1800 -ih, kada je nervni sustav bio podijeljen na animalni (npr. vezan za senzornu percepciju i dobrovoljni motorni odgovor) i vegetativni dio (npr. osigurava nutritivne funkcije) « (Steven LAUREYS, Traumatic brain damage. Severe brain damage: coma and disorders of consciousness, u: Donald W. Pfaff (ur.), Neuroscience in the $21^{\text {st }}$ Century, New York, Springer, 2016, 3341-3368, 3356.

${ }^{14}$ Bryan JENNETT, Fred PLUM, Persistent vegetative state after brain damage. A syndrome in search of name, Lancet, 1 (1972) 734-737, 734, prema L. Syd M. JOHNSON, Moving beyond end of life. The ethics of disorders of consciousness in an age of discovery and uncertainty, u: Martin M. Monti, Walter G. Sannita (ur.), Brain Function and Responsiveness in Disorders of Consciousness, Cham, Springer, 2016, 185-194, 186.
} 
nesvjesno stanje, tada se može razborito raspraviti potrebu nastavljanja mjera održavanja«. ${ }^{15}$

Johnson, nadovezujući se na tu njihovu izjavu, ukazuje na to da tzv. ustaljena predrasuda »beznađa« osoba u PVS-u ne zahvaća samo medicinsku, već i bioetičku sferu te da u pojedinim bioetičkim raspravama bivaju rabljene različite sintagme, poput »sudbina gora od smrti«, »beskoristan pokušaj«, »ne-umrli«, »ležeći u otvorenom grobu« itd. Nažalost, ove sintagme s vremenom prerastaju u uopćene zaključke u kojima pojedinci, koncentrirajući se na samosvijest kao bitan i karakterizirajući element ljudske osobe, zalaze u krajnost pojednostavnjenog zaključivanja, insistirajući da je tijelo u PVS-u izgubilo sve oznake osobe te da ne preostaje ništa drugo već je smatrati mrtvom. ${ }^{16}$

Takvo se mišljenje još više ustalilo pojavom različitih aktivizama i pokreta "prava na smrt" PVS pacijenata, koji vuče svoje korijene iz slučaja Karen Ann Quinlan. ${ }^{17}$ Stoga to isto »beznađe«, koje se odnosilo na prognozu oporavka osobe koja se nađe u PVS-u, postaje ispolitizirani koncept pro-eutanazijskih pokreta. Tu ispolitiziranost primjećuje i jedan od poznatih američkih bioetičara, Joseph J. Fins, koji smatra da su slučaj Karen Ann Quinlan i »pravo na smrt« postale »značajne kulturne sile $\aleph^{18}$ koje su oblikovale mišljenje, ne samo javnosti, već i samih liječnika, da je prekid postupaka održavanja na životu ili njihova uskrata u takvim slučajevima dobra klinička praksa koja se dalje proširuje ne samo na osobe u vegetativnom stanju, već i na ostala stanja poremećaja svijesti. ${ }^{19}$

Početkom 1990-ih, na osnovi pojedinih slučajeva, uviđa se nekonzistentnost tvrdnje Jenetta i Pluma da je vegetativno stanje trajno i ireverzibilno te se uvodi značajna razlika koja se temelji na vremenskom kriteriju između perzistentnog i trajnog vegetativnog stanja. Uviđa se potreba za uvođenjem razlike između trajnog stanja, koje ne pruža mogućnost oporavka i u kojem osoba ostaje do smrti, tj. ono je ireverzibilno, te perzistentnog koje pruža otvorenost za mogućnost oporavka. ${ }^{20}$ Posljedica je to različitih slučajeva koji su potvrdili mogućnost oporavka iz vegetativnog stanja, no bioetičarka L. Syd M. Johnson ističe da se,

\footnotetext{
${ }^{15}$ Isto, 186.

${ }^{16}$ Usp. isto, 186.

${ }^{17}$ John S. Finns u svojoj knjizi svjedoči o mladoj djevojci Karen Ann Quinlan koja je, pomiješavši alkohol i lijekove, pala u komu i poslije nekoliko dana počela otvarati oči pa su zaključili da je u vegetativnom stanju. Budući da je bila spojena na respirator, roditelji su tražili skidanje s njega jer je ventilacija u njezinu slučaju bila izvanredno sredstvo, liječnici to nisu dopustili. Roditelji su slučaj predali sudu koji je, poslije dugotrajnog procesa u kojem je svjedočio i dr. Fred Plum, presudio skidanje s respiratora. Dr. Plum se nije iznenadio sučevoj presudi, jer je u dijagnostičkom postupku utvrđivanja stvarnoga bolesničinog stanja, je li u vegetativnom stanju ili mrtva na osnovu kriterija moždane smrti, isključio ventilator i utvrdio da diše samostalno (usp. Fins, Rights come to Mind..., 36-41).

${ }^{18}$ Isto, 41.

${ }^{19}$ Usp. isto.

${ }^{20}$ Zanimljivo je istaknuti da se to razlikovanje nije ustalilo u hrvatskome jeziku, štoviše ustalilo se poimanje vegetativnog stanja u obliku trajnog vegetativnog stanja.
} 
nažalost, trajno i perzistentno često poistovjećuju, kako u javnosti, tako i u bioetičkoj literaturi. ${ }^{21}$ Stoga je ta uvedena razlika stvorila još veću konfuziju, ne samo među laicima, nego i u akademskim krugovima.

Unatoč tome uvidjelo se da pojedini pacijenti, koji su doživjeli napredak iz PVS-a, ne zadovoljavaju dijagnostičke kriterije ni za komu niti za vegetativno stanje. Štoviše, osobe u tom stanju pokazivale su nekonzistentne, ali razlučive tragove svijesti te je stoga Aspen Neurobehavioral Conference Work Group ${ }^{22}$ uvažila ove promjene te ih definirala kao stanje minimalne svijesti (MCS), predloživši da bi se dijagnosticiranje ovog novog stanja trebalo bazirati na specifičnim obilježjima ponašanja samosvijesti i svjesnosti svoga okružja, a koje se ne mogu pronaći ni u komatoznom ni u vegetativnom stanju. Ovaj preokret osobito je značajan zato što osobe u MCS-u mogu iskusiti bol i patnju te imaju mogućnost emocionalne reakcije na slušanje glasa ili prepoznavanja lica članova obitelji, možda i prijatelja. Osobe u MCS-u efektivnije odgovaraju na terapije, stoga, u odnosu na osobe u UWS-u, imaju znatno veće mogućnosti za dugotrajan oporavak. ${ }^{23}$ Nastanak nekih slučajeva ${ }^{24}$ i bolje uviđanje razlika među tim stanjima, nije nimalo uzdrmalo dotadašnju predrasudu »beznađa« za oporavak osoba u takvome stanju. Međutim, zasigurno su potakli znatiželju za boljim razumijevanjem takvih stanja kojemu će značajno doprinijeti kasnija neuroznanstvena istraživanja.

\section{Neuroznanstvena dekonstrukcija »beznađa«}

Posljednja tri desetljeća, razvitkom novih dijagnostičkih tehnologija, kao što su funkcionalno oslikavanje mozga (PET/CT, ${ }^{25} \mathrm{MRI},{ }^{26} \mathrm{fMRI}^{27}$ ) ili različiti dijagnostički alati koji mjere elektro-fiziološke signale (EEG, ${ }^{28} \mathrm{ERP},{ }^{29} \mathrm{EmnG}^{30}$ ), poboljšano je razumijevanje već spomenutih stanja. One su osobito otvorile nove vidike preciznijem dijagnosticiranju i prognoziranju različitih poremećaja svijesti. Upravo su ove nove dijagnostičke metode pripomogle da se uvidi kako

\footnotetext{
${ }^{21}$ Usp. Johnson, Moving beyond end of life..., 187.

${ }^{22}$ Joseph T. GIACINO i dr., The minimally conscious state - definition and diagnostic criteria, Neurology, 58 (2002) 3, 349-353.

${ }^{23}$ Usp. Johan STENDER, Albert GJEDDE, Steven LAUREYS, Detection of Consciousness in the Severely Injured Brain, u: J. L. Vincent (ur.), Annual Update in Intensive Care and Emergency Medicine 2015, Cham, Springer, 2015, 495-506, 495-496.

${ }^{24}$ Usp. Wakoto MATSUDA i dr., Awakenings from persistent vegetative state. Report of three cases with parkinsonism and brain stem lesions on MRI, Journal of Neurology, Neurosurgery $\mathcal{E}$ Psychiatry, 74 (2003) 1571-1573.

${ }^{25}$ Pozitronska emisijska tomografija.

${ }^{26}$ Magnetska rezonanca.

${ }^{27}$ Funkcionalna magnetska rezonanca.

${ }^{28}$ Elektroencefalogram.

${ }^{29}$ Kognitivni evocirani potencijali.

${ }^{30}$ Elektromiografija.
} 
u pojedinim slučajevima dolazi do prijelaza iz VS-a u MCS, tj. da ova tranzitivna mogućnost daje nadu za oporavak osoba u VS-u. Među onima koji su udarili temelje daljnjim istraživanjima, bila je istraživačka skupina Adriana Owena, koja je, koristeći se fMRI-om, kod osobe s prvotno dijagnosticiranim VS-om otkrila tragove svjesnosti pa čak i mogućnost slijeđenja nekih naredbi. Na upit pacijentici da zamisli kako igra tenis ili se kreće po kući, na fMRI-u se uvidjela aktivacija određenog dijela mozga. Te su dvije aktivnosti kasnije iskorištene kao binarni odgovori u obliku da ili ne, kojima je pacijentica odgovarala na kratka i jednostavna pitanja. Drugim riječima, istraživači su postavljali pitanja $\mathrm{s}$ unaprijed objašnjenim značenjem koja radnja predstavlja koji odgovor, dok je osoba odgovarala na njih zamišljajući igranje tenisa ili šetnju po kući. ${ }^{31}$

$\mathrm{Na}$ to se istraživanje, vezano za uspostavljanje komunikacije s pacijentima u VS-u, nadovezuju istraživanja Martina M. Montija koji također, služeći se većim uzorkom od 54 pacijenta, od kojih $23 \mathrm{~s}$ dijagnosticiranim vegetativnim stanjem, a 31 sa stanjem minimalne svijesti, uspostavlja s njih 5 (od 54) komunikaciju putem aktivacije nekih moždanih zona potaknutih voljnim odgovorima na postavljene im zadatke. Od tih 5 , njih 4 je pripadalo u skupinu pacijenata s dijagnosticiranim VS-om. ${ }^{32}$ Ova istraživanja su doprinijela čak i boljem razumijevanju i diferenciranju samog MCS-a, gdje se na temelju podataka uvidjelo da postoje dva različita tipa MCS-a koji se odnose na visoki stupanj svijesti (npr. praćenje naredbi) i MCS-a kod jednostavnih i ne refleksnih odgovora (npr. praćenje očima, kontingentni odgovor na emocionalni stimulans itd.). ${ }^{33}$

Posljednja tri desetljeća neuroznanstvenih istraživanja doprinijela su ujedno i boljem određenju i redefiniranju »sindroma bez imena«. Tako je, uvidjevši postojeću zbunjenost već spomenutom razlikom između izdržljivoga i trajnog vegetativnog stanja, europska istraživačka grupa (European Taskforce), predvođena Stevenom Laureysom, ${ }^{34}$ predložila promjenu imena iz vegetativnog stanja $\mathrm{u}$ sindrom neosjetljive budnosti (unresponsive wakefulness syndrome - UWS). ${ }^{35}$ Promjena imena nije samo riješila pojmovnu konfuziju, već je zapravo doprinijela rješavanju stigmatiziranosti i predrasuda koje su vezane uz pojam »vegetativan«, skrenuvši pažnju na budnost i nereagiranje, a ne na nesvjesnost osobe. Ujedno se napušta dotad sigurno stajalište da ne postoji nikakva mogućnost oporavka iz UWS-a te se ostavlja mogućnost oporavka. ${ }^{36}$ Štoviše, mijenja se

\footnotetext{
${ }^{31}$ Usp. Adrian M. OWEN i dr., Detecting awareness in the vegetative state, Science, 313 (2006) 5792, 1402.

${ }^{32}$ Usp. Martin M. MONTI i dr., Willful Modulation of Brain Activity in Disorders of Consciousness, The New England Journal of Medicine, 362 (2010) 579-589.

${ }^{33}$ Usp. Laureys, Traumatic brain damage. Severe brain damage..., 3341-3342.

${ }^{34}$ Usp. Steven LAUREYS i dr., Unresponsive wakefulness syndrome: a new name for the vegetative state or apallic syndrome, BMC Medicine, 8 (2010) 1, 68.

${ }^{35}$ Dalje u tekstu umjesto PVS ili VS ćemo upotrebljavati kraticu UWS.

${ }^{36}$ Usp. Johnson, Moving beyond end of life..., 189.
} 
dotad ustaljeno mišljenje da je oporavak moguć jedino u okviru prve godine, ${ }^{37}$ te da poslije prve godine osoba prelazi u permanentno stanje u kojem više nema nikakve mogućnosti za napredak. naime, s vremenom se, kroz različite slučajeve, uvidjelo da neki pacijenti koji su bili dijagnosticirani kao osobe u UWS-u, pokazuju povremene tragove svjesnosti sebe i drugih te da ne pripadaju u tu kategoriju.

Stoga su takvi slučajevi potakli istraživače da se posvete boljem razumijevanju UWS-a i preciznosti njegova dijagnosticiranja i mogućnosti oporavka. Ovakav oporavak ogleda se u većini slučajeva u tranzitivnosti iz UWS-a u MCS. Različita istraživanja poljuljala su sigurnost u mogućnost oporavka u roku od godine dana, dokazavši kako taj limit ne može sa sigurnošću biti potvrđen budući da su se oni u svojem istraživanju susreli sa slučajevima oporavka pacijenata čak nakon četiri ili više godina. ${ }^{38}$ Stoga, neuroznanstvena istraživanja ne dovode samo u pitanje »beznadnost«, već i njenu predmnijevanu »zagarantiranost« ili »sigurnost « granice nemogućeg oporavka, ostavljajući otvorena vrata nesigurnosti. ${ }^{39}$ Time se daje prvenstvo pravoj naravi svijesti koja po sebi nije binarna.

Cjelokupna dotad predmnijevana sigurnost dijagnosticiranja vegetativnog stanja i njegove adekvatne prognoze osporena je istraživanjem Van Erpa i suradnika, ${ }^{40}$ pokazavši na reprezentativnom uzorku pacijenata dijagnosticiranih u UWS/VS-u: čak njih $40 \%$ bilo je pogrešno dijagnosticirano i zapravo su se nalazili u MCS-u. Tim se istraživanjem osporila ne samo pouzdanost dotad korištenog kliničkog instrumenta Glasgowske ljestvice kome, već i pokazala nemogućnost preciznog određenja razdoblja kada će i hoće li uopće pacijent doživjeti taj tranzitivni prijelaz iz UWS-a u jedno od drugih stanja poremećaja svijesti. Jedan od poznatijih slučajeva pogrešne dijagnoze jest slučaj Terryja Wallisa, koji je dospio na naslovnice kad je, nakon 19 godina provedenih s dijagnozom »vegetativnoga stanja«, progovorio. Steven Laureys ističe da etiketiranost vegetativnog stanja i predrasuda njegova »beznađa « uzrokuju da se prvi znaci oporavka svijesti često propuštaju od strane liječnika i obitelji. ${ }^{41}$ Ove pogrešne dijagnoze ne trebaju izazvati nepovjerenje prema liječničkim dijagnozama, jer se, štoviše, u posljednje vrijeme pribjegava korištenju kombinacije Glasgowske revidirane ljestvice kome i drugih različitih tehnologija oslikavanja mozga.

\footnotetext{
${ }^{37}$ Usp. THE MULTI-SOCIETY TASK FORCE ON PVS, Medical aspects of the persistent vegetative state (1), The New England Journal of Medicine 330 (1994) 1499-1508; THE MULTISOCIETY TASK FORCE ON PVS, Medical aspects of the persistent vegetative state (2), The New England Journal of Medicine, 330 (1994) 1572-1579.

${ }^{38}$ Usp. Steppacher, Kaps, Kissler, Will time heal?..., 406-407.

${ }^{39}$ Usp. Johnson, Moving beyond end of life..., 188.

${ }^{40}$ Usp. Willemijn S. VAN ERP i dr., The vegetative state. Prevalence, misdiagnosis, and treatment limitations, Journal of the American Medical Directors Association, 16 (2015) 1, 85.e9-85.e14.

${ }^{41}$ Usp. Laureys, Traumatic brain damage..., 3358.
} 
No, činjenično stanje jest da su tehnologije poput PET/CT i fMRI rijetko zastupljene u svim bolnicama, najviše zbog nedostatka novca. Štoviše, i tamo gdje takvi uređaji postoje, ne treba zanemariti činjenicu da su troškovi dijagnosticiranja vrlo visoki, a to otežava postupak pružanja precizne i adekvatne dijagnoze. Upravo takvo globalno stanje motiviralo je istraživače da pronađu prihvatljivije i dostupnije metode, a jedna od obećavajućih je, primjerice, međusklop računalo-mozak, tzv. BCI (Brain-computer interface) koje se temelji na već postojećim i primjenjivim tehnologijama encefalograma (EEG-a), kognitivnih evociranih potencijala (ERP-a) ili elektromiografiji (EMG-a). ${ }^{42}$

Štoviše, u posljednje se vrijeme traže i druge solucije koje bi potakle napredak i oporavak svijesti u UWS slučajevima. Te nove metode temelje su na novim tehnologijama stimulacije (od invazivne do neinvazivne) različitih dijelova centralnog i perifernog nervnog sustava. Jedan od takvih pristupa je i stimulacija vagusa nervusa, pa tako imamo nedavno objavljenu studiju gdje je, $s$ pomoću te stimulacije u trajanju od mjesec dana, pacijent koji je ležao 15 godina s dijagnosticiranim vegetativnim stanjem, počeo pokazivati znakove napretka, primjerice, povećanu razinu podražaja, ustaljenu pažnju, pokretljivost tijela i vizualno praćenje. ${ }^{43}$

Stoga ovi novi načini dijagnosticiranja nisu samo uvid u stanje uma, nego i u mogući oporavak te se ne smiju temeljiti na preferencijalno vrijednosnom odabiru, već na kliničkoj i neurološkoj procjeni. ${ }^{44}$ Potrebno je istaknuti da je dijagnozu je li netko svjestan ili nije, čak i s ovim novim tehnologijama, vrlo teško točno utvrditi. ${ }^{45}$ Određenje svijesti i razine svjesnosti je ponajprije epistemološki problem, jer mi, kao subjekt koji promatra, možemo zaključiti o postojanju svjesnosti drugoga ne iz direktnog uvida, već samo na temelju indirektnih znakova. No, taj epistemološki problem povezan je s ontologijom i naravi same svijesti. Bez obzira na te poteškoće preciziranja svjesnosti i nesvjesnosti, ne smijemo zakoračiti u »centrizam svijesti« jer time zanemarujemo cjelokupnost osobe.

Najnovije dijagnostičke tehnologije (PET/CT, (f)/MRI, EMG, ERP, EmnG) možda će u budućnosti jamčiti veću sigurnost kvantitativne procjene i prognosticiranja (ne)povratnosti stupnja svijesti, no ne smije se zaboraviti tehnologizacijski potencijal u tim novim dijagnostičkim metodama kod slučajeva gdje osobe posjeduju stanovitu razinu svijesti koja ne pokazuje nikakve mjerljive manifestirajuće znakove pa se ne može nikako ni prepoznati. Dakle, svijest postoji u kontinuumu sve dok postoje aktivni procesi u mozgu, što je zapravo i ontološki gledano kompatibilnije nego dosadašnje poimanje svjesnosti. Dru-

\footnotetext{
${ }^{42}$ Usp. isto, 3360.

${ }^{43}$ Usp. Martina CORAZZOL i dr., Restoring consciousness with vagus nerve stimulation, Current Biology, 27 (2017) 18, R994-R996, R994.

${ }^{44}$ Usp. Fins, Rights come to Mind..., 127.

${ }^{45}$ Usp. L. Syd M. JOHNSON, Inference and inductive risk in disorders of consciousness, American Journal of Bioethics. Neuroscience, 7 (2016) 1, 35-43.
} 
gim riječima mozak uvijek posjeduje minimalni oblik svjesnosti, koji zapravo predstavlja, koliko to god paradoksalno zvučalo, »nesvjesnu svjesnost«, što zapravo odgovara »neodražavajućoj svjesnosti« (npr. kad osjetimo različite stvari, a nismo svjesni da se to događa upravo sada). ${ }^{46}$

Tome u prilog idu i posljednja istraživanja u psihologiji koja ukazuju na to da svijest nije direktno povezana $\mathrm{s}$ emocijama. ${ }^{47}$ Štoviše, najnovije hipoteze u psihologiji, na temelju novih uvida, pretpostavljaju da se emocije događaju $\mathrm{u}$ pozadini, a mi ih postajemo svjesni naknadno, tj. u procesima nad kojima svjesnost nema direktnu kontrolu. ${ }^{48}$ Sve više i više se uviđa bitnost i uloga nesvjesnoga u svijesti, nadasve njihova međusobno povezana ovisnost koja nas potiče zapravo da promislimo zašto bi samo svijest imala dominantnu moralnu relevantnost $u$ etičkim raspravama ${ }^{49}$ Stoga, naša skrb mora biti adekvatna i integralna te uzimati konkretnu osobu u cjelini sa svim njezinim potrebama svjesne i nesvjesne sfere.

\section{Etičke, pravne i društvene implikacije dekonstruiranog $» b e z n a d a \ll$}

Znanstveni doprinos dekonstrukciji ustaljene predrasude »beznađa« poljuljao je ne samo znanstvenu sferu, već i domenu kliničke prakse. Postavilo se pitanje kako ubuduće postupati s pacijentima koji se nalaze u različitim stanjima poremećaja svijesti. Rezultati ovih istraživanja također su ostavili svoj neizbrisivi trag $u$ okvirima etičkih rasprava, jer dosadašnje se postupanje $s$ takvim osobama upravo temeljilo na beznadnosti stanja, tj. nemogućnosti za daljnji oporavak, što je često navodilo na isključivanje potpornih sredstava za održavanje života. Dosadašnja praksa na tom putu »beznađa«, već u samom procesu postavljanja dijagnoze kreće od pretpostavke da pacijent ne bi želio biti "prikopčan na aparate« ili živjeti takvim životom te se, kao mogućem rješenju, priklanja prestanku nutricije i hidratacije, što je zapravo u većini slučajeva pasivna eutanazija.

Zapravo, takvo postupanje ne samo da zadire u okvire kliničkog donošenja odluka, već i u domenu etike, tj. moralnog postupanja. Vodi se prvenstveno

\footnotetext{
${ }^{46}$ Usp. Michele FARISCO, Steven LAUREYS, Kathinka EVERS, The intrinsic activity of the brain and its relation to levels and disorders of consciousness, Mind EMatter, 15 (2017) 2, 197-219, 198-199.

${ }^{47}$ Usp. Michele FARISCO, We need a more comprehensive ethics of disorders of consciousness (18.09.2017), https://www.bioedge.org/indepth/view/we-need-a-more-comprehensive-ethicsof-disorders-of-consciousness $/ 12522$ ?utm_source $=$ BioEdge\&utm_campaign $=11 \mathrm{e} 88 \mathrm{f} 98 \mathrm{ba}$ EMAIL_CAMPAIGN_2017_11_18\&utm_medium $=$ email\&utm_term =0_76ab23e62c11e88f98ba-124710227 (19.10.2017).

${ }^{48}$ Usp. Oakley, Halligan, Chasing the rainbow..., 1924.

${ }^{49}$ Usp. Michele FARISCO, Kathinka EVERS, The ethical relevance of the unconscious, Philosophy, Ethics, and Humanities in Medicine, 12 (2017) 1, 11.
} 
ideologiziranim načelom »kvalitete života«, koje je ostavilo neizbrisiv trag na to što znači »dobra klinička praksa« u ovakvim slučajevima. Razlikovanje svjesnosti i nesvjesnosti u kliničkoj praksi ima veći etički teret nego što bi trebao, jer se obitelji i surogatni donositelji odluke suočavaju s teškim rješenjima koja se tiču nastavka potpornih mjera održavanja pacijenta na životu. ${ }^{50}$ Stoga su rezultati novih istraživanja doveli u pitanje dosadašnje moralno postupanje s tim pacijentima, čime se međunarodna bioetička scena našla između dvaju stajališta. S jedne strane su zagovornici koji su za postupanje slično dosadašnjoj praksi, samo uz bolje informiranje obitelji i surogata koji donose odluke, ${ }^{51}$ dok su s druge strane oni koji u ovim rezultatima vide prekretnicu te sa stajališta etike prava zastupaju mišljenje da osobe koje su povratile tragove svijesti od samog tog trenutka imaju pravo na život. ${ }^{52}$

Iako rezultati ukazuju na to da postoji mogućnost oporavka kod osoba s različitim poremećajima svijesti, zagovornicima stare ustaljene prakse uz bolje informiranje, to nije značajan indikator vezan za kvalitetu života te iste osobe. Njihova skeptičnost oslanja se na epistemološku problematiku mogućnosti uvida i preciziranja ima li netko svijest ili ne te, štoviše, ističu da je u ovom trenutku vrlo teško precizno razlikovati UWS i MCS.$^{53} \mathrm{No}$, zanimljivo je da ne niječu važnost ovih novih otkrića, jer kako i sami navode, oni su važni da bi se obitelj i surogatni donositelj odluke adekvatno informirali o prognozi stanja pacijenta i mogućnosti njegova oporavka. Ovakav pristup ne stavlja u središte svijest, već vrijednost osobe koja je u UWS-u ili MCS-u, a obitelji i surogatnom donositelju odluke čini presudan faktor u donošenju rješenja. Valja istaknuti, iako je »beznađe« dekonstruirano u stajalištu ovih zagovornika, ono je ostalo u preferencijalnim odlukama baziranim na ideologiziranoj kvaliteti života. Problematika kod donošenja odluka u ovim slučajevima jest da su nepouzdane, jer obitelj ili surogatni donositeljii odluke često nisu dostato informirani o tim i takvim stanjima pa o njima imaju različite predrasude..$^{54}$ Međutim, ovakva perspektiva počiva na »prognostičkom pesimizmu« koji uvjerava obitelj i surogatne donositelje odluke na rješenje o dokidanju potpornih mjera održavanja pacijenta na životu. Često su prognoze utemeljene na začaranom krugu statističkoga broja smrtnosti pacijenata u dotičnom stanju, ne ističući da su neki umrli upravo zbog prekidanja hidratacije i nutricije, što ohrabruje odluku drugih te povećava

\footnotetext{
${ }^{50}$ Usp. L. Syd M. JOHNSON, Known unknowns. Disorders and prognosis in disorders of consciousness, American Journal of Bioethics. Neuroscience, 8 (2017) 3, 145-146, 145.

${ }^{51}$ Usp. David FISCHER, Robert D. TRUOG, The problems with fixating on consciousness in disorders of consciousness, American Journal of Bioethics. Neuroscience, 8 (2017) 3, 135-140.

${ }^{52}$ Usp. Fins, Rights come to Mind..., 286-311.

${ }^{53}$ Usp. Fischer, Truog, The problems with fixating on consciousness..., 139-140.

${ }^{54}$ Usp. Matthew BRADDOCK, The uncertainty of consciousness and why it is important, American Journal of Bioethics. Neuroscience, 8 (2017) 3, 155-157, 157.
} 
tu istu razinu smrtnosti, ne dajući pacijentima pravu priliku za preživljavanje i oporavak. ${ }^{55}$

Međutim, ova dekonstrukcija beznađa nije ostavila ravnodušnim nikoga unutar bioetičke sfere. Tako su naznake svijesti prvenstveno služile kao indikator za fluidnost tih stanja, tj. njihovu nestalnost ili trajnost. Među tim zagovornicima su jedni od začetnika istraživanja o stanjima poremećaja svijesti, učenici Jenetta i Pluma, Nicholas D. Schiff i Joseph J. Fins. Oni su uvidjeli da istraživanja utječu na dekonstrukciju dosadašnje predrasude o trajnosti tih stanja. Na temelju toga istaknuli su da se stanja nazvana UWS ili MCS razlikuju od dijagnoza koje su najčešće trajne, jer se ta stanja s vremenom mogu promijeniti. ${ }^{56}$ No, imajući dobre namjere da se dosadašnja ustaljena praksa promijeni, pred zadanim izazovima zalaze u domenu etike prava, $t \mathrm{j}$. ističu da osobe koje su ostvarile neke naznake svijesti imaju određena prava. Slijedeći ovu logiku razmišljanja, zauzimaju antropološki neutemeljen stav, jer pridajući prava osobama koje pokazuju znake svijesti, impliciraju da osobe koje su u UWS-u nemaju ta prava, $\mathrm{tj}$. da svijest određuje nositelja prava, a ne njegovo ljudsko dostojanstvo ukorijenjeno u njegovoj egzistenciji. Ovakvo stajalište zalazi u već spomenuti »centrizam svijesti« gdje se svijest uzima kao ona koja determinira je li netko osoba ili nije, tj. posjeduje li prava ili ne.

Ostavljajući po strani ova dva polarizirana stajališta koja svoje utemeljenje pronalaze $\mathrm{u}$ funkcionalnom poimanju čovjeka, želimo se zapitati ima li ova dekonstrukcija »beznađa« etičke implikacije. Ona mijenja cjelokupnu sliku o vegetativnom stanju i drugim stanjima poremećaja svijesti kao trajnih i nepromjenjivih. Dekonstruiranjem beznadnosti teži se prvenstveno buđenju moralne odgovornosti prema tim osobama i preispitivanju naših postupaka skrbi za te osobe. No, može se zaključiti da ta moralna odgovornost u suvremenoj bioetičkoj raspravi ima antropološko utemeljenje u kojem je prisutnost svijesti jedini indikator. Uzimanje svijesti za relevantan indikator za moralnu odgovornost prema tim osobama, po svemu je sudeći ograničeno gledište. Stoga moralna odgovornost ne smije zanemariti antropološku cjelovitost čovjeka, a ta cjelovitost se jedino pronalazi u monističkoj viziji čovjeka, a ne dualističkoj - kao što smo imali prigodu vidjeti u aktualnim bioetičkim raspravama gdje je čovjek shvaćen kao um koji egzistira unutar tijela. Monistička vizija čovjeka uzima kao integrativno jedinstvo duše i tijela, gdje svijest nije esencija ljudskoga bića, već je svijest samo jedna od ključnih i izražajnih karakteristika ljudskoga bića. ${ }^{57}$ Prema toj perspektivi, postojanje ili nepostojanje svijesti ne može biti indikator egzistencije ljudskoga bića. Upravo neuroznanstveni rezultati koji potvrđuju

\footnotetext{
${ }^{55}$ Usp. Johnson, Known unknowns. Disorders and prognosis..., 146.

${ }^{56}$ Usp. Joseph J. FINS, Nicholas D. SCHIFF, Differences that make a difference in disorders of consciousness, American Journal of Bioethics. Neuroscience, 8 (2017) 3, 131-134.

${ }^{57}$ Usp. Douglas C. MCADAMS, Kevin W. CONLEY II, Kevin G. DONOVAN, Cogitas Ergo Es? Metaphysical humility in disorders of consciousness, American Journal of Bioethics. Neuroscience, 8 (2017) 3, 147-148.
} 
fluidnost svijesti, isključuju dobro poznate filozofske tvrdnje ${ }^{58}$ da se osobom smatra samo ono biće koje posjeduje samosvijest, jer kad bi se uzelo u obzir ove nove neuroznanstvene pokazatelje, svatko ima mogućnost da u nekoj teškoj bolesti bude osoba pa onda malo da ne bude, pa opet da bude.

Ovakvo promišljanje nema logičku konzistentnost pa je jasno da nekonzistentnost te tvrdnje traži plauzibilnije rješenje, a to je ontološko poimanje osobe. Iz te perspektive o osobi se može reći samo jedno: da postoji ili ne postoji, da jest ili nije, nema nešto između. Osoba u UWS ili MCS stanju prvenstveno je osoba u ontološkom smislu. Postojanje svijesti ili ne zapravo je ne čini više ili manje osobom, stoga što je svijest samo jednua od funkcija koja je karakteristična za čovjeka. Polazeći od takve integrativne vizije čovjeka, ono na što nas moralna odgovornost poziva, oslanjajući se na dosadašnje neuroznanstvene rezultate, jest važnost preciznog dijagnosticiranja i prognoziranja da bi se pružila adekvatna skrb. Adekvatna skrb se osobito odnosi na terapije koje se razlikuju kod osoba u UWS-u i MCS-u. ${ }^{59}$ Iako smo uvidjeli iz samih istraživanja da je teško utvrditi postojanje svijesti te prepoznati prelazak iz UWS-a u MCS, to ne znači da se radi sigurnosti ne bismo mogli voditi u takvim slučajevima načelom opreznosti. ${ }^{60}$ Ono je već primijenjeno bioetičko načelo u domeni biotehnologija. ${ }^{61}$ Vođeni ovim načelom, kako ističe Braddock, bolje je za nekoga pretpostaviti da ima svijest te mu ne dokinuti potporne mjere održavanja na životu, nego pretpostaviti da nema svijest, a zapravo je ima, te mu dokinuti potporne mjere održavanja na životu. Stoga bi se dalo zaključiti da bi naše postupanje prema osobama koje se nađu u takvom stanju trebalo uključiti ovu mogućnost nesigurnosti preciznog određenja svijesti.

Pored svih predstavljenih rješenja i smjernica kako postupati pred izazovima koje su pred nas stavila nova neuroznanstvena istraživanja, adekvatno rješenje već postoji te se čak i prakticira glede konkretnih odluka vezanih za potporne mjere održavanja na životu. Ona su pružena od strane pape Pija XII. u obliku redovitih i izvanrednih sredstava (proporcionalnih i neproporcionalnih), a koja počivaju na integralnoj antropološkoj viziji čovjeka. ${ }^{62}$ Poslije se papa Ivan Pavao II. osobito osvrće (s ovim smjernicama) na osobe u vegetativnom stanju. ${ }^{63}$ Ove smjernice ne prave razliku između osoba koje imaju ili nemaju svijest, već promatraju čovjeka s njegovim intrinzičnim dostojanstvom i pravi-

\footnotetext{
${ }^{58}$ Usp. Peter SINGER, Practical ethics, New York, Camridge Universtiy Press, 2011, 85.

${ }^{59}$ Usp. Ariane LEWIS, Sometimes, it's okay to judge a patient by their diagnosis, American Journal of Bioethics. Neuroscience, 8 (2017) 3, 143-144, 144.

${ }^{60}$ Usp. Braddock, The uncertainty of consciousness..., 156.

${ }^{61}$ Usp. Valerije VRČEK, Čuvanje i razvoj stvorenoga. Načelo opreznosti - znanstvena korekcija pohlepe, Bogoslovska smotra, 76 (2006) 2, 417-427.

${ }^{62}$ Usp. PIO XII., Discorso sulla rianimazione (24. studeni 1957.), u: E. Natali (ur.), Bioetica e magistero: da Pio XII a Papa Francesco, Medinova, Favara, 2015, 790-793.

${ }^{63}$ Usp. IVAN PAVAO II., Discorso ai partecipanti al Congresso Internazionale Life-Sustaining treatments and vegetative state (20. ožujka 2004.), u: E. Natali (ur.), Bioetica e magistero. Da Pio XII a Papa Francesco, Favara, Medinova, 2015, 845-849.
} 
ma koje mu po njemu pripadaju. Stoga su one više orijentacijske naravi, dakle ne baziraju se na analizi ideologizirane kvalitete života, tj. ne uzimaju oporavak kao relevantno mjerilo nastavka života. Vidjeli smo da su se etičke rasprave i polarizacija u bioetičkom svijetu upravo rasplamsale oko pitanja prekidanja hidratacije i nutricije. Međutim, hidratacija i nutricija su redovita sredstva koje smo moralno dužni pružiti pacijentu sve do trenutka dok ne postanu nepotrebna i medicinski beskorisna u slučaju kada pacijent više ne može apsorbirati hranu ${ }^{64}$ te njihovo davanje nema više smisla. ${ }^{65}$

Vidjeli smo da ova neuroznanstvena dekonstrukcija ima, prema Josephu J. Finsu, pravne posljedice, no cjelokupna interpretacija ovih neuroznanstvenih rezultata biva uzeta kao otkriće koje pruža novo svjetlo na prava koja se osobama u UWS-u uskraćuju. Štoviše, postojanje svijesti je, prema njima, indikator za priznavanje prava, što zapravo počiva, kako smo već imali prilike vidjeti, na krivom dualističkom poimanju čovjeka. Na takav pokušaj »logike« zaključivanja, Ariane Lewis postavlja pitanje: »Zašto bi pacijent $u$ jednom kliničkom stanju imao drugačija prava od pacijenta u drugom kliničkom stanju? ${ }^{66}$ Drugim riječima, kakva to veća prava može imati pacijent u UWS-u od pacijenta u MCS-u? Može se jedino reći da su zbog predrasude »beznađa« prava na adekvatnu skrb, točniju dijagnozu pacijentima u UWS-u bila zakinuta zbog ishitrenih odluka prekidanja hidratacije i nutricije, tj. pasivnom eutanazijom. Stoga bi jedini zaključak zapravo bio, kako i sama Lewis ističe, da se priznavanje prava ne bi trebalo ni u kojem slučaju oslanjati na prisutnost svijesti ili njenu odsutnost te bi pacijenti trebali imati prava bez obzira na svoju dijagnozu. ${ }^{67}$

Dakle, možemo uvidjeti da je sama dekonstrukcija »beznađa« izazov za cjelokupno društvo u kojem treba postojati moralna odgovornost svih za osobe $\mathrm{u}$ stanjima poremećaja svijesti. Prema tome, taj izazov može biti jedino savladiv načelom solidarnosti, ${ }^{68}$ koje treba pretočiti u djelo sva ona prava koja pripadaju ljudskoj osobi prema njezinu intrinzičnom dostojanstvu, a ne prema postojanju ili nepostojanju svijesti. Prava bi solidarnost na djelu bila: razviti metodologije preciznijeg dijagnosticiranja - od različitih neuroznanstvenih tehnika pa do kliničkih skala - te pomoću njih nastojati kontinuiranim praćenjem, koliko je moguće, precizno dijagnosticirati u kom se stanju pacijenti nalaze i na temelju te dijagnoze pružiti svakome adekvatnu terapiju i mogućnost za oporavak te primjereno informirati obitelj i surogatne donositelje odluke da ne bi donijeli

\footnotetext{
${ }^{64}$ Usp. Joseph BOYLE, A catholic approach to wiholding medically provided food and water, u: Jason T. Eberl (ur.), Contemporary controversies in Catholic Bioethics, Springer, Cham, 2017, 436-437.

${ }^{65}$ Usp. Suzana VULETIĆ i dr., Biomedicinski i moralno-etički aspekti distanazije. U agoniji umiranja pred medicinskom beskorisnošću, Diacovensia, 22 (2014) 2, 163-200.

${ }^{66}$ Lewis, Sometimes, it's okay to judge a patient by their diagnosis..., 143.

${ }^{67}$ Usp. isto.

${ }^{68}$ Usp. Matti HÄYRY, European values in bioethics. Why, what, and how to be used, Theoretical Medicine and Bioethics, 24 (2003) 3, 199-214.
} 
ishitrena rješenja te svakome omogućiti pristup redovnim sredstvima održavanja na životu. ${ }^{69}$ Takvom solidarnošću ispunit će se prava osoba te će se ujedno i njihovo intrinzično dostojanstvo prepoznati u punini.

\section{Umjesto zaključka}

Uz nastojanje boljeg razlikovanja između moždane smrti i stanja poremećaja svijesti, usporedno se kreirala predrasuda »beznađa«, za koju su sigurno zaslužni, no nenamjerno, sami pokretači toga diferenciranja. U ovom je slučaju poznati problem komunikacije znanstvenih istraživanja i njihove interpretacije u javnosti, uzeo svoj danak u odlukama o prekidanju potpornih mjera održavanja na životu takvih pacijenata. Moglo se uvidjeti, iako se ta predrasuda iznjedrila iz znanosti, da je sama znanost boljim uvidom putem neuroznanstvenih istraživanja dokazala njenu nekonzistentnost i pobila je u potpunosti. Štoviše, sama taksonomija stanja poremećaja svijesti se mijenja bolje precizirajući i ne ostavljajući mjesta predrasudi »beznađa«. Ova ustaljena predrasuda »beznađa« možda i ne bi bila tolik problem da nema direktan utjecaj na pesimističku prognozu pacijentova oporavka odmah nakon uspostavljanja dijagnoze UWS-a. Prognostički pesimizam, pored svoje praktične dimenzije, ima još veću i težu moralnu dimenziju koja se puno puta odrazila u drastičnim posljedicama za život samih pacijenata. Stoga se dosadašnja praksa temeljila na prekidanju hidratacije i nutricije ubrzo nakon uspostavljanja dijagnoze. Takvo preispitivanje ne samo da je dotaknulo kliničku praksu, već je ponukalo i etičku raspravu koja se većinom usredotočila na činjenicu postojanja ili nepostojanja svijesti. Iz ove se suvremene etičke rasprave uvidjelo kako se teško odvojiti od ustaljene predrasude »beznađa«, izvlačeći se na nemogućnost preciznog određenja postojanja ili nepostojanja svijesti. Fokusiranjem samo na svijest i njeno trenutno postojanje, gubi se pravo značenje ovih neuroznanstvenih istraživanja. Naime, oporavak kod ovih stanja poremećaja svijesti jest moguć i ona nisu trajna i ireverzibilna, kako se mislilo dosad. Upravo ovaj krucijalan podatak dekonstruktira u potpunosti »beznađe« te pruža integralnu sliku čovjeka više od same svijesti. Jedino na takvoj antropološkoj slici čovjeka može se bazirati skrb za osobe s različitim poremećajima svijesti, pritom se oslanjajući na razliku između redovitih i izvanrednih sredstava pred izazovima kliničke prakse.

\footnotetext{
${ }^{69}$ Usp. Golan G. OFRA, Marcus ESTHER-LEE, Should we provide life-sustaining treatments to patients with permanent loss of cognitive capacities, Rambam Maimonides Medical Journal, 2 (2012) 3, e0018.
} 


\section{Anto Čartolovni* \\ Neuroscientific deconstruction of the ideologised »hopelessness « of the vegetative state \\ Summary}

Recent neuroscientific research challenges today's prejudice of a vegetative state as a »hopeless « state. The results from these findings not only destroy the actual existing prejudices about people in a vegetative state, but they also provide a new insight into the epistemological problematics of the accurate diagnostic process of the actual state, followed up with ethical and social implications. They also provide a better understanding of the mere nature of consciousness and awareness, implying the moral and social responsibility towards these people, and at the same time leaving no place for »hopelessness«. Therefore, the primary aim of this article is to demonstrate how, with the development of these new insights into the state of disorders of consciousness, side by side, from the mere beginning has been developing prejudice of »hopelessness «, as a side-effect of insufficient and inadequate knowledge related to the nature of consciousness in the vegetative state. This conformity prejudice has had direct influence on clinical decision-making regarding artificial life-sustaining measures: from hydration and nutrition withdrawal, to do not resuscitate orders, and finally to ventilator withdrawal, retaining that the person has no hope for recovery after the determination of the vegetative state diagnosis. Furthermore, this prejudice of »hopelessness « has not only deeply paved the morally doubtful way for performing passive euthanasia, but was, even more, misused and politicised as one of the main arguments and examples of the pro-euthanasia movements in the fight for euthanasia legalisation.

Key words: vegetative state, bioethics, neuroethics, disorders of consciousness, life-sustaining measures, hopelessness.

(na engl. prev. Anto Čartolovni)

\footnotetext{
* Anto Čartolovni, PhD, Postdoctoral research fellow, Catholic University of Croatia; Address: Ilica 242, HR-10000 Zagreb, Croatia; E-mail: anto.cartolovni@unicath.hr.
} 